\title{
Spotted knapweed response to season and frequency of mowing
}

\author{
MATTHEW J. RINELLA, JAMES S. JACOBS, ROGER L. SHELEY, AND JOHN J. BORKOWSKI
}

Authors are graduate research assistant, post-doctoral research associate, and associate professor, respectively, Department of Land Resources and Environmental Science and associate professor, Department of Mathematical Sciences, Montana State University, Bozeman, Mont. 59717.

\begin{abstract}
Spotted knapweed (Centaurea maculosa Lam.) is a non-indigenous weed that has invaded millions of hectares of rangeland in the United States. Mowing may be useful for reducing this weed. Our objective was to investigate the response of spotted knapweed and grasses to season and frequency of mowing. Response of grass and spotted knapweed to $\mathbf{1 6}$ mowing treatments applied annually for 3 years was studied at 2 sites. Treatments consisted of combinations of spring, summer, and fall mowing. Treatments were arranged in a randomized-complete-block design with 4 replications (16 treatments; 4 replications; 2 sites $=128$ plots). After repeating mowing treatments for 3 years, a single fall mowing when spotted knapweed was in the flowering or seed producing stage reduced its cover and adult density as much as any treatment consisting of repeated mowing. Fall mowing decreased adult density 85 and $83 \%$ below that of the control at Sites 1 and 2 , respectively. Treatments reduced seedling density at Site 2 , but the response was not consistent between years or among treatments. Spotted knapweed cover was decreased by several mowing treatments at each site (10-36\%), while grass cover was only decreased by 3 mowing treatments $(18-23 \%)$ at Site 1 in 1998. We recommend a single annual mowing, applied at the flowering or seed producing stage, for the partial control of spotted knapweed.
\end{abstract}

Key Words: Centaurea maculosa, density, cover, weed control

Grassland ecosystems of the western United States, once dominated by native grasses, now contain extensive areas dominated by non-indigenous weeds, such as spotted knapweed (Centaurea maculosa Lam.) (Roché and Talbott 1986). Spotted knapweed, a perennial in the Asteraceae family, was introduced to the Pacific Northwest around 1900 (Strang et al. 1979). This species now infests over 2.2 million hectares in 5 northwestern states and is spreading rapidly (Chicoine et al. 1985, Sheley and Rice 1995). Research suggests that weeds like knapweed may degrade soil and water resources (Lacey et al. 1989), reduce biodiversity (Tyser and Key 1988, Randall 1996), diminish wildlife habitat and livestock forage production (Spoon et al. 1983, Thompson 1996), and alter the functioning of the ecosystem (Randall 1996).

Various tools have been developed and used for controlling rangeland weeds. The most effective herbicide, picloram (4amino-3, 5, 6-trichloropicolinic acid), can control spotted knapweed for 2 to 5 years, but the weed reestablishes after the herbicide dissipates (Davis 1990). Several species of insects have been

\footnotetext{
Manuscript accepted 2 Apr. 2000.
}

\section{Resumen}

El "Spotted Knapweed" (Centaurea maculosa Lam.) es un maleza introducida que ha invadido millones de hectáreas de pastizal en Estados Unidos. La siega puede ser útil para reducir esta maleza. Nuestro objetivo fue investigar la respuesta del "Spotted knapweed"y los zacates a la época y frecuencia de segado. Se estudio la repuesta de los zacates y el "Spotted knapweed" a 16 tratamientos de siega aplicados anualmente durante 3 años en dos sitios experimentales. Los tratamientos consistieron en la combinación de segado en primavera, verano y otoño. Los tratamientos se evaluaron bajo un diseño de bloques completos al azar con cuatro repeticiones (16 tratamientos; 4 repeticiones; 2 sitios $=128$ unidades experimentales). Después de repetir los tratamientos de siega por 3 años, una sola siega en otoño, cuando el "Spotted knapweed"estaba en las etapas de floración o producción de semilla, redujo su cobertura y la densidad de plantas adulto tanto como cualquiera de los tratamientos de siega repetida. La siega en otoño disminuyo la densidad de adultos en 83 y $85 \%$ con respecto a la densidad de las parcelas control de los sitios 1 y 2 respectivamente. Los tratamientos redujeron la densidad de plántulas en el sitio 2 , pero la respuesta no fue consistente entre años ni entre tratamientos. En cada sitio la cobertura de "Spotted knapweed" disminuyo (10-36\%) en respuesta de algunos de los tratamientos de siega múltiple, mientras la cobertura de los zacates del sitio 1 disminuyó (18-23\%) en 1998 en solo 3 de los tratamientos de siega. Para el control parcial de "Spotted knapweed" recomendamos una sola siega aplicada en las etapas de floración o producción de semilla.

released for controlling knapweed (Rees et al. 1996). In some instances, these natural enemies have reduced seed output and damaged roots (Story et al. 1989), but they have not successfully decreased plant density. Repeated grazing by sheep has resulted in reduced knapweed density and lowered reproduction (Olson et al. 1997). Also, sheep have minimal impact on associated grasses if grazing occurs when plants are dormant. More recently, revegetation of infested rangeland has shown some potential for successful weed management, but environmental and economic considerations associated with this intensive system require its thoughtful use (Lym and Tober 1997, Ferrel et al. 1998).

Mowing is a management tool that may reduce spotted knapweed. Kennett et al. (1992) found that repeated partial defoliation of spotted knapweed in a greenhouse experiment reduced root and crown weight. Decreased root and crown weight can reduce long-term survival of individual plants (Bula and Smith 1954, Menke and Trlica 1981). Watson and Renny (1974) reported that 
the density of diffuse (Centaurea diffusa Lam.) and spotted knapweed plants that produced seed was reduced from 34.3 plants $\mathrm{m}^{-2}$ in the control to 7.8 and 0.3 plants $\mathrm{m}^{-2}$ when mowing occurred during the bud and flowering stage, respectively. Mowing during the flowering stage reduced seed germination to $17.9 \%$ compared to $91.1 \%$ in the control. The effects of mowing on knapweed are not fully understood (Sheley et al. 1998). Currently, mowing is not extensively used for managing knapweed. Repeated mowing within a season has not been studied, and the optimum season for mowing has not been determined.

Our objective was to determine the effect of mowing frequency and season on spotted knapweed density and knapweed, grass, litter, and bare ground cover when treatments were repeated in 3 consecutive growing seasons. We believed that frequent removal of biomass would maximize plant injury and that late-season mowing would damage plants more than early- and mid-season mowing because more biomass is removed. Because of morphological differences between forbs and grasses, we believed that mowing would remove more knapweed biomass than grass biomass as a percentage of total plant weight. If true, this suggested that mowing might affect knapweed more adversely than grasses. We hypothesized that: 1) spotted knapweed would decrease as mowing frequency increased, 2) lateseason mowing would decrease spotted knapweed more than early- and mid-season mowing, and 3) mowing would decrease spotted knapweed cover more than grass cover.

\section{Materials and Methods}

\section{Study Sites}

This study was conducted at 2 sites from 1996 through 1998. Site 1 was located 1 $\mathrm{km}$ south of Belgrade, Mont. $\left(45^{\circ} 47^{\prime} \mathrm{N}\right.$, $\left.111^{\circ} 10^{\prime} \mathrm{W}\right)$ at an elevation of $1,349 \mathrm{~m}$. This site was within the Festuca idahoensis-Agropyron spicatum habitat type (Mueggler and Stewart 1980) and was dominated by spotted knapweed, smooth brome (Bromus inermis Leyss.), and cheatgrass (Bromus tectorum L.). The soil is a Beaverell gravelly loam (loamy-skeletal over sandy or sandy-skeletal, mixed, Aridic Argiustoll).

Site 2 was located $15 \mathrm{~km}$ southwest of Bozeman, Montana $\left(45^{\circ} 36^{\prime} \mathrm{N}, 111^{\circ} 5^{\prime} \mathrm{W}\right)$ at an elevation of $1,340 \mathrm{~m}$. This site was also within the Festuca idahoensis-Agropyron spicatum habitat type (Mueggler and Stewart 1980) and was dominated by spotted knapweed, Idaho fescue (Festuca idahoensis Elmer), bluebunch wheatgrass (Agropyron spicatum Pursh), and Kentucky bluegrass (Poa pratensis L). The soil is $70 \%$ Beaverton cobbly loam (loamy-skeletal over sandy or sandyskeletal, mixed, Typic Argiboroll) and $30 \%$ Hyalite loam (fine-loamy, mixed, Typic Argiboroll).

Monthly precipitation data were collected for both sites. Weather stations were located 1.6 and $4.5 \mathrm{~km}$ north of Sites 1 and 2 , respectively.

\section{Experimental Design}

Treatments consisted of 15 mowing regimes and a control. The mowing treatments were: 1 spring mowing (SP1); 1 summer mowing (SU1); 1 fall mowing (F1); 2 spring mowings (SP2); 2 summer mowings (SU2); 2 fall mowings (F2); 1 spring and 1 summer mowing (SP1-SU1); 1 spring and 1 fall mowing (SP1-F1); 1 summer and 1 fall mowing (SU1-F1); 1 spring, 1 summer, and 1 fall mowing (SP1-SU1-F1); 2 spring and 2 summer mowings (SP2-SU2); 2 spring and 2 fall mowings (SP2-F2); 2 summer and 2 fall mowings (SU2-F2); 2 spring, 2 summer, and 2 fall mowings (SP2-SU2-F2); a treatment consisting of mowing at 2 week intervals throughout the growing season (2WK); and a control that received no mowing (NONMOWN). Growth stage of spotted knapweed and date were recorded at each mowing. Treatments were arranged in a randomized-complete-block design with 4 replications. A rotary gasoline-powered push mower with a $53-\mathrm{cm}$ long blade set at a height of $10 \mathrm{~cm}$ was used for mowing, and treatments were applied to $1.8-\mathrm{m}^{2}$ plots. We believed this cutting height would maximize removal of knapweed biomass while removing relatively little grass biomass during mid- and late-season mowing. Treatments were applied in 1996 and were repeated on the same plots in 1997 and 1998.

\section{Sampling}

Data were collected 22 September through 26 September in 1997 and 28 September through 2 October in 1998 from a randomly placed 20 x 50-cm frame in each plot. Measurements included spotted knapweed seedling and adult density and knapweed, grass, bare ground, and litter cover, visually estimated as a percentage of plot surface area. Knapweed plants between the cotyledon and 2-leaf stage were counted as seedlings. Plants consist- ing of a rosette with or without reproductive shoots were counted as adults.

\section{Data Analysis}

Data from Sites 1 and 2 were analyzed separately because of differences in species composition between sites. Data were analyzed as a split-plot in time with mowing treatment as the whole-plot factor and year as the sub-plot factor. Individual means were compared using a least significant difference test at the $5 \%$ level of confidence. In order to provide experimentwise error protection, least significant differences were not calculated unless effects were significant at the $5 \%$ level of confidence in the analysis of variance Ftests (Fisher 1960).

\section{Results and Discussion}

Precipitation was similar between sites (Table 1). It was wetter in 1997 than in 1998 with significant rainfall occurring in every month during the 1997 growing season. Late summer precipitation was lower in 1998 than in 1997. Growth stage of spotted knapweed was similar for each mowing treatment among years (Table 2).

Table 1. Monthly precipitation within growing season on 2 study sites in south central Montana.

\begin{tabular}{llcll}
\hline \hline Site & Month & 1996 & 1997 & 1998 \\
\hline \multirow{2}{*}{1} & & -------- & $(\mathrm{mm})---------$ \\
& Apr. & 9.86 & 27.93 & 26.70 \\
& May & 28.14 & $*^{\mathrm{a}}$ & 34.92 \\
& Jun. & 22.59 & 58.13 & 79.90 \\
& Jul. & trace & 84.42 & 13.76 \\
& Aug. & 6.57 & 31.02 & 15.61 \\
& Sep. & 18.90 & 31.43 & 16.02 \\
& Apr. & 34.51 & 47.86 & 27.11 \\
& May & 90.17 & 87.30 & 28.14 \\
& Jun. & 20.75 & 92.22 & 102.29 \\
& Jul. & trace & 51.14 & 11.30 \\
& Aug. & 14.58 & 41.70 & 21.98 \\
& Sep. & 22.18 & 53.61 & 19.72 \\
\hline
\end{tabular}

${ }^{\mathrm{a}}$ Missing precipitation data.

\section{Bare Ground and Litter Cover}

Year or mowing did not affect amount of litter cover at either site (Table 3). Treatment or year did not affect amount of bare ground at Site 1, but treatment and year had a significant effect on bare ground at Site 2 (Table 3). Bare ground increased with mowing frequency at that site (Fig. 1). Amount of bare ground was higher in 1997 (22\%) than in 1998 (14\%) at Site 2. 


\section{Spotted Knapweed Seedling Density}

Spotted knapweed seedling density was affected by mowing at both sites (Table $3)$. The response of seedling density to mowing varied with year only at Site 2 (Table 3). Most mowing treatments reduced seedling density below the control at Site 2, and the magnitude and consistency of seedling reductions increased with mowing frequency. No mowing regime reduced seedling density below the control at Site 1 (Table 4).

Seedling establishment can be strongly affected by the soil surface environment (Harper et al.1965), and frequent mowing may have altered the soil microenvironment making it less suitable for seedling establishment. In this study, seedlings were too short to be cut by the mower blade, but blowing soil during mowing may have injured seedlings and enhanced seedling mortality. Watson and Renny (1974) found that mowing could reduce spotted knapweed seed production and germination. Reductions in seedling density likely resulted from reduced seed production in this study. Reduced seedling recruitment may lead to decreases in density of plants over time.

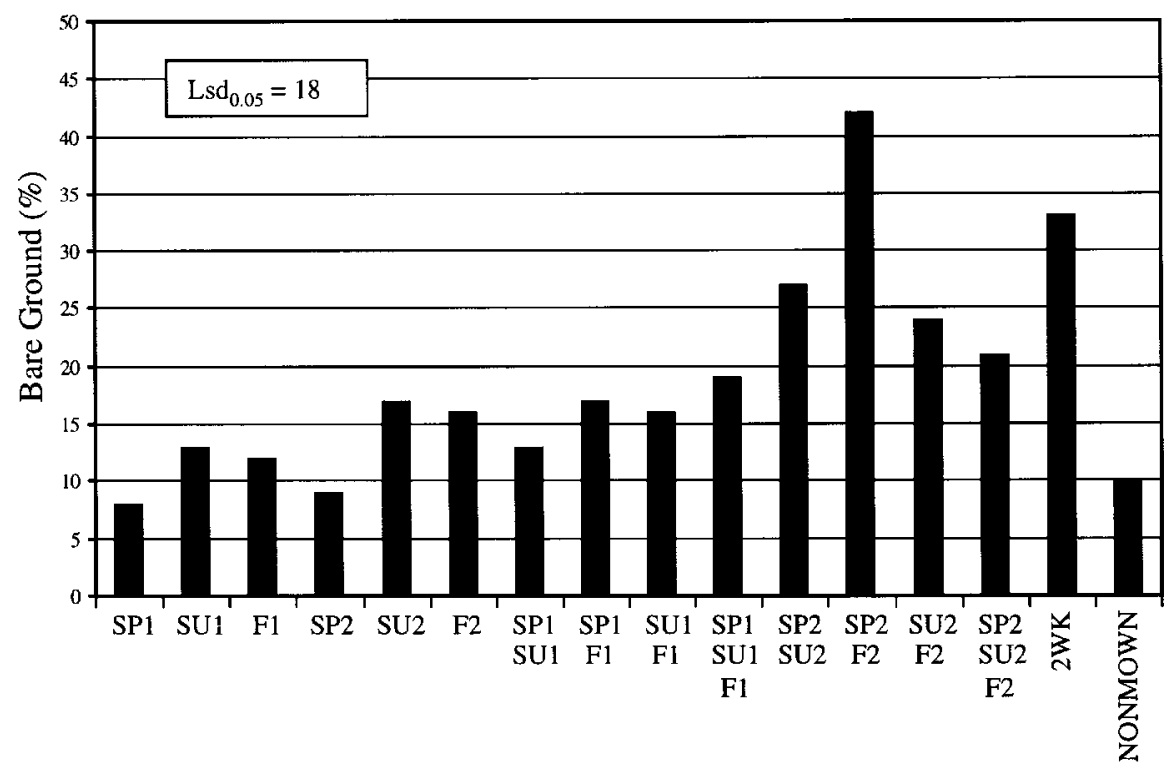

Fig. 1. Effect of various mowing treatments repeated over years (1996-98) on bare ground at Site 2 in south central Montana.

\section{Spotted Knapweed Adult Density}

The effect of mowing on spotted knapweed adult density was dependent on year at both sites (Table 3). Adult density increased during the study period in the control at Site 1 (Table 4). However, adult density did not increase during the study
Table 2. Mowing dates and spotted knapweed growth stages for various mowing treatments repeated over years (1996-98) on 2 sites in south central Montana.

\begin{tabular}{|c|c|c|c|c|c|c|}
\hline \multirow{3}{*}{$\begin{array}{l}\text { Mowing } \\
\text { Treatments }\end{array}$} & \multicolumn{6}{|c|}{ Year } \\
\hline & \multicolumn{2}{|c|}{1996} & \multicolumn{2}{|c|}{1997} & \multicolumn{2}{|c|}{1998} \\
\hline & Date & Stage & Date & Stage & Date & Stage \\
\hline$\overline{\text { SP1 }}$ & $22 / 5$ & $\mathrm{r}^{\mathrm{a}}$ & $15 / 5$ & $\mathrm{r}$ & $20 / 5$ & $\mathrm{r}$ \\
\hline \multirow[t]{2}{*}{ SP2 } & $22 / 5$ & $r$ & $15 / 5$ & $r$ & $20 / 5$ & $\mathrm{r}$ \\
\hline & $5 / 6$ & b & $29 / 5$ & b & $3 / 6$ & b \\
\hline SU1 & $19 / 6$ & b & $11 / 6$ & b & $17 / 6$ & b \\
\hline \multirow{2}{*}{ SU2 } & $19 / 6$ & b & $11 / 6$ & b & $17 / 6$ & $b$ \\
\hline & $3 / 7$ & bu & $25 / 6$ & bu & $1 / 7$ & $\mathrm{f}$ \\
\hline F1 & $21 / 8$ & $\mathrm{f} / \mathrm{s}$ & $21 / 8$ & $\mathrm{f} / \mathrm{s}$ & $26 / 8$ & $\mathrm{~s}$ \\
\hline \multirow[t]{2}{*}{ F2 } & $21 / 8$ & $\mathrm{f} / \mathrm{s}$ & $21 / 8$ & $\mathrm{f} / \mathrm{s}$ & $26 / 8$ & $\mathrm{~s}$ \\
\hline & $4 / 9$ & $\mathrm{~s}$ & $4 / 9$ & $\mathrm{~s}$ & $9 / 9$ & $\mathrm{~s}$ \\
\hline \multirow[t]{10}{*}{$2 \mathrm{WK}$} & $22 / 5$ & $\mathrm{r}$ & $15 / 5$ & $\mathrm{r}$ & $20 / 5$ & $\mathrm{r}$ \\
\hline & $5 / 6$ & b & $29 / 5$ & b & 3.6 & b \\
\hline & $19 / 6$ & b & $11 / 6$ & b & $17 / 6$ & b \\
\hline & $3 / 7$ & b & $25 / 6$ & bu & $1 / 7$ & $\mathrm{f}$ \\
\hline & $17 / 7$ & $\mathrm{f}$ & $9 / 7$ & f & $15 / 7$ & $\mathrm{f}$ \\
\hline & $31 / 7$ & $\mathrm{f} / \mathrm{s}$ & $23 / 7$ & $\mathrm{f}$ & $29 / 7$ & f/s \\
\hline & $10 / 8$ & $\mathrm{f} / \mathrm{s}$ & $7 / 8$ & $\mathrm{f} / \mathrm{s}$ & $12 / 8$ & $\mathrm{f} / \mathrm{s}$ \\
\hline & $21 / 8$ & $\mathrm{~s}$ & $21 / 8$ & $\mathrm{f} / \mathrm{s}$ & $26 / 8$ & $\mathrm{~s}$ \\
\hline & $4 / 9$ & $\mathrm{~s}$ & $4 / 9$ & $\mathrm{~s}$ & 9/9 & $\mathrm{s}$ \\
\hline & $18 / 9$ & $\mathrm{~s}$ & $18 / 9$ & $\mathrm{~s}$ & $23 / 9$ & $\mathrm{~s}$ \\
\hline
\end{tabular}

$\mathrm{r}=$ rosette, $\mathrm{b}=\mathrm{bolt}, \mathrm{bu}=\mathrm{bud}, \mathrm{f}=$ flowering, $\mathrm{s}=$ seed bearing. period where summer and/or fall mowing occurred at this site. Mid- to late- season mowing may discourage increases in adult density. The control had similar adult densities in 1997 and 1998 at Site 2.

Every mowing regime, except the treatment consisting of 1 spring mowing, decreased spotted knapweed adult density below the control at Site 1 in 1998 (Table 4). No treatment decreased adult density below the control at Site 1 in 1997. Most treatments decreased adult density at Site 2 in both years.

Fall mowing was more effective than spring or summer mowing at Site 1 in 1997 and at both sites in 1998. Late season mowing removes more spotted knapweed biomass and may enhance knapweed mortality. Late season precipitation was low at both sites in 1998, and moisture stress may have inhibited knapweed recovery (Table 1).

A single fall mowing, when spotted knapweed was in the flowering or seed producing stage, reduced knapweed cover and adult density as much as any treatment consisting of repeated mowing at both sites in 1998 (Table 4 and 5). Although a single fall mowing each fall did not affect adult density after 2 years (1996-97), 1 fall mowing for 3 years (1996-98) decreased adult plant density. Annual mowing may have an additive effect on knapweed density. Mowing after the initiation of bolting removes the apical meristem from knapweed plants. Plants that survive this mowing initiate growth from lateral buds resulting in knapweed plants with a decumbent growth habit (Devlin and Witham 1983). 
Table 3. Mean squares and degrees of freedom (df) for main and interaction effects where the response of frequency and timing of mowing on spotted knapweed and grasses was measured in 1997-98 on 2 sites in south central Montana.

\begin{tabular}{|c|c|c|c|c|c|c|c|c|}
\hline \multirow[b]{3}{*}{ Site } & \multirow[b]{3}{*}{ Source } & \multirow[b]{3}{*}{ df } & \multicolumn{5}{|c|}{ Mean Squares } & \\
\hline & & & \multicolumn{2}{|c|}{ Knapweed Density (plants $\mathrm{m}^{-2}$ ) } & \multicolumn{4}{|c|}{ Cover $(\%)$} \\
\hline & & & Seedling & Adult & Knapweed & Grass & Litter & Bare ground \\
\hline \multirow[t]{7}{*}{$\overline{1}$} & REP & 3 & $231187.5^{*^{\mathrm{a}}}$ & $5520.8^{*}$ & 42.3 & $650.0^{*}$ & $4729.4^{*}$ & $6262.5^{*}$ \\
\hline & MOW $^{\mathrm{b}}$ & 15 & $228695.8 *$ & $10838.3^{*}$ & $309.7 *$ & 309.3 & 649.7 & 1145.9 \\
\hline & REP*MOW & 45 & $89675.3^{*}$ & 1652.5 & 41.8 & $303.3^{*}$ & $741.7 *$ & $883.5^{*}$ \\
\hline & YEAR & 1 & 59512.5 & 378.1 & 10.1 & 608.1 & 1029.4 & 1568.0 \\
\hline & REP*YEAR & 3 & 79270.8 & 2444.8 & $218.6^{*}$ & $403.9 *$ & $1455.7 *$ & 368.9 \\
\hline & YEAR*MOW & 15 & 102572.5 & $3863.1 *$ & $141.8^{*}$ & $223.2^{*}$ & 548.5 & 349.8 \\
\hline & ERROR & 45 & 44319.7 & 1112.0 & 52.9 & 105.7 & 363.8 & 268.5 \\
\hline \multirow[t]{7}{*}{2} & REP & 3 & 21628.1 & 1805.2 & 13.5 & $630.6^{*}$ & 820.4 & $854.9^{*}$ \\
\hline & MOW & 15 & $29194.8 *$ & $22248.1^{*}$ & $583.1 *$ & 180.9 & 718.4 & $670.4^{*}$ \\
\hline & REP*MOW & 45 & 6665.3 & $4458.5^{*}$ & $107.8 *$ & $207.5^{*}$ & 552.3 & $302.5^{*}$ \\
\hline & YEAR & 1 & $363378.1^{*}$ & 50.0 & 409.7 & 220.5 & 2547.2 & $2072.1 *$ \\
\hline & REP*YEAR & 3 & 20103.1 & 3160.4 & $217.1 *$ & $204.1 *$ & $1812.4^{*}$ & 29.9 \\
\hline & YEAR*MOW & 15 & $22673.1^{*}$ & $7650.0^{*}$ & $165.8 *$ & 50.3 & 382.3 & 164.2 \\
\hline & ERROR & 45 & 9184.8 & 2344.9 & 57.0 & 50.6 & 443.3 & 159.7 \\
\hline
\end{tabular}

${ }_{\mathrm{a}}^{\mathrm{a}}$ Mean squares followed by $*$ are significant at the $5 \%$ level of confidence.

${ }^{\mathrm{b}}$ Mowing treatment effect.

Plants with a prostrate growth habit are not likely to be affected because very little biomass is removed during mowing. For this reason, repeated mowing typically does not cause further reductions in adult knapweed density. The season of mowing is more important than mowing frequency in reducing adult density.

Depletion of carbohydrate reserves in response to defoliation has been shown to cause plant death in some instances (Weinmann 1948) and may explain reductions in plant density in these experiments. However, the results of a sheep grazing study indicate that growth and survival of spotted knapweed are not correlated with carbohydrate reserves (Olson and Wallander 1997). Sheep grazed grasses more intensively than knapweed in that study. Relative defoliation pressure applied to knapweed and grasses may be different in mown systems than in grazed systems because of livestock preferences. The lower growth habit of grasses may allow them to escape severe defoliation from mowing. Decreased knapweed carbohydrate reserves and light grass defoliation could interact to decrease knapweed density.

\section{Knapweed and Grass Cover}

The effect of mowing on spotted knapweed cover depended on year at both sites (Table 3). The effect of mowing on grass cover depended on year at Site 1, and grass cover was not affected by year or mowing at Site 2 (Table 3).

Only 3 treatments (SU1, F1, and SP2F2) decreased percent cover of grass below the control at Site 1 in 1998 (Table 5). Two treatments (SP1-SU1 and SU2-
F2) consisting of repeated mowing increased grass cover above the control at Site 1 in 1997. No treatment affected cover of grass at Site 2.

While only a few treatments decreased percent cover of grass below the control, spotted knapweed cover and adult density were severely decreased by several mowing treatments. Conversely, Kennett et al. (1992) measured final foliage weight per pot and found that knapweed was less sensitive than bluebunch wheatgrass to defoliation in a greenhouse experiment. Reductions in knapweed cover and density in our experiment resulted from plant death that occurred in response to 3 years

Table 4. Response of spotted knapweed density to various mowing treatments repeated over years (1996-98) on 2 sites in south central Montana.

\begin{tabular}{|c|c|c|c|c|c|c|c|}
\hline \multirow{3}{*}{$\begin{array}{l}\text { Mowing } \\
\text { Treatment }\end{array}$} & \multicolumn{3}{|c|}{ Site 1} & \multicolumn{4}{|c|}{ Site 2} \\
\hline & \multirow{2}{*}{$\frac{\text { Seedling }^{\mathrm{a}}}{1997-98}$} & \multicolumn{2}{|c|}{ Adult } & \multicolumn{2}{|c|}{ Seedling } & \multicolumn{2}{|c|}{ Adult } \\
\hline & & 1997 & 1998 & 1997 & 1998 & 1997 & 1998 \\
\hline-- & \multicolumn{7}{|c|}{$(\mathrm{Pla}$} \\
\hline SP1 & 504 & 98 & 148 & 20 & 288 & 78 & 130 \\
\hline SU1 & 135 & 128 & 93 & 18 & 90 & 93 & 175 \\
\hline $\mathrm{F} 1$ & 542 & 43 & 28 & 95 & 115 & 173 & 35 \\
\hline SP2 & 598 & 53 & 128 & 33 & 210 & 95 & 208 \\
\hline SU2 & 152 & 30 & 45 & 35 & 100 & 128 & 148 \\
\hline $\mathrm{F} 2$ & 303 & 20 & 10 & 98 & 53 & 115 & 30 \\
\hline SP1-SU1 & 172 & 63 & 48 & 8 & 240 & 130 & 178 \\
\hline SP1-F1 & 448 & 48 & 15 & 90 & 148 & 80 & 23 \\
\hline SU1-F1 & 324 & 20 & 45 & 50 & 28 & 53 & 68 \\
\hline SP1-SU1-F1 & 251 & 63 & 45 & 5 & 63 & 45 & 48 \\
\hline SP2-SU2 & 157 & 70 & 25 & 0 & 140 & 35 & 50 \\
\hline SP2-F2 & 119 & 28 & 10 & 33 & 173 & 48 & 8 \\
\hline SU2-F2 & 213 & 23 & 25 & 25 & 80 & 83 & 53 \\
\hline SP2-SU2-F2 & 108 & 40 & 18 & 3 & 70 & 43 & 33 \\
\hline $2 \mathrm{WK}$ & 91 & 45 & 25 & 3 & 70 & 53 & 50 \\
\hline NONMOWN & N 382 & 65 & 183 & 93 & 445 & 210 & 205 \\
\hline $\operatorname{Lsd}_{0.05}$ & 303 & & & & & & \\
\hline
\end{tabular}

The year by treatment interaction was not significant at the $5 \%$ level of confidence, so treatment means were averaged across years. that 1 year of clipping reduced knapweed root, crown, and foliage at final harvest, and this weakening of plants may result in plant death if clipping treatments are continued for multiple years. Blaisdell and Pechanec (1949) found that annual clipping at the soil level affected biomass production of the indigenous forb arrowleaf balsamroot [Balsamorhiza sagittata (Pursh) Nutt.] less severely than bluebunch wheatgrass. In our study, mowing treatments removed much less biomass, and this may explain differences in the responses of these 2 studies. of mowing. Kennett et al. (1992) found 
Table 5. Response of spotted knapweed and grass cover to various mowing treatments repeated over years (1996-98) on 2 sites in south central Montana

\begin{tabular}{|c|c|c|c|c|c|c|}
\hline \multirow[b]{3}{*}{ Mowing Treatment } & \multicolumn{4}{|c|}{ Site 1} & \multirow{2}{*}{\multicolumn{2}{|c|}{$\begin{array}{c}\text { Site } 2^{\mathrm{a}} \\
\text { Knapweed }\end{array}$}} \\
\hline & \multicolumn{2}{|c|}{ Knapweed } & \multicolumn{2}{|c|}{ Grass } & & \\
\hline & 1997 & 1998 & 1997 & 1998 & 1997 & 1998 \\
\hline & \multicolumn{6}{|c|}{-0} \\
\hline SP1 & 15 & 32 & 26 & 25 & 16 & 25 \\
\hline SU1 & 20 & 16 & 20 & 6 & 20 & 21 \\
\hline F1 & 10 & 9 & 15 & 6 & 24 & 5 \\
\hline SP2 & 13 & 35 & 18 & 23 & 24 & 37 \\
\hline SU2 & 10 & 10 & 21 & 21 & 24 & 21 \\
\hline $\mathrm{F} 2$ & 9 & 4 & 25 & 15 & 15 & 5 \\
\hline SP1-SU1 & 16 & 9 & 44 & 31 & 29 & 21 \\
\hline SP1-F1 & 9 & 5 & 18 & 19 & 18 & 7 \\
\hline SU1-F1 & 10 & 9 & 21 & 16 & 9 & 7 \\
\hline SP1-SU1-F1 & 13 & 9 & 19 & 18 & 10 & 7 \\
\hline SP2-SU2 & 8 & 6 & 15 & 29 & 9 & 8 \\
\hline SP2-F2 & 6 & 4 & 21 & 11 & 6 & 4 \\
\hline SU2-F2 & 10 & 11 & 41 & 15 & 21 & 6 \\
\hline SP2-SU2-F2 & 11 & 4 & 33 & 16 & 15 & 7 \\
\hline $2 \mathrm{WK}$ & 9 & 4 & 16 & 22 & 19 & 9 \\
\hline NONMOWN & 16 & 26 & 19 & 29 & 29 & 40 \\
\hline $\operatorname{Lsd}_{0.05}$ & & & & & & \\
\hline
\end{tabular}

${ }^{\mathrm{a}}$ Grass cover was not affected by mowing at Site 2 at the $5 \%$ level of confidence.

\section{Conclusions}

Spotted knapweed cover was decreased more severely and consistently than grass cover by mowing. Mowing appeared to shift the competitive balance in favor of grasses, and for this reason, repeating mowing regimes for multiple years may cause a decrease in spotted knapweed and a corresponding increase in grasses.

Mowing can decrease spotted knapweed seedling density, but the response varied with site and year in this study. Several mowing regimes decreased spotted knapweed adult density below the control. After repeating mowing regimes for 3 years, a single fall mowing, when spotted knapweed was in the flowering or seed producing stage, reduced spotted knapweed cover and adult density as much as any treatment consisting of repeated mowing. Season of mowing appears more important than mowing frequency in reducing adult spotted knapweed density. We recommend a single annual mowing, applied at the flowering or seed producing stage, for the partial control of spotted knapweed.

\section{Literature Cited}

Blaisdell, J.P. and J.F. Pechanec. 1949. Effects of herbage removal at various dates on vigor of bluebunch wheatgrass and arrowleaf balsamroot. J. Ecol. 30:298-305.

Bula, R.J. and K. Smith. 1954. Cold resistance and chemical composition in overwintering alfalfa, red clover and sweetclover. Agron. J. 46:397-401. 1985. Predicting weed migration from soil and climate maps. Weed Sci. 34:57-61.

Davis, E.S. 1990. Spotted knapweed (Centaurea maculosa L.) seed longevity, chemical control and seed morphology. M.S. Thesis, Montana State Univ. Bozeman, Mont.

Devlin, M.D. and F.H. Witham. 1983. Plant Physiology. Prindle, Weber and Schmidt. Boston, Mass.

Ferrell, M.A., T.D. Whitson, D.W. Koch, and A.E. Gade. 1998. Leafy spurge (Euphorbia esula) control with several grass species. Weed Technol. 12:374-380.

Fisher, R.A. 1960. The Design of Experiments, 7th ed. Hafner. New York.

Harper, J.L., J.T. Williams, and G.R. Sagar. 1965. The behavior of seeds in soil. Part 1 . The heterogeneity of soil surfaces and its role in determining the establishment of plants from seed. J. Ecol. 53, 273-286.

Kennett, G.A., J.R. Lacey, C.A. Butt, K.M. Olson-Rutz, and M.R. Haferkamp. 1992. Effects of defoliation, shading and competition on spotted knapweed and bluebunch wheatgrass. J. Range Manage. 45:363-369.

Lacey, J.R., C.B. Marlow, and J.R. Lane. 1989. Influence of spotted knapweed (Centaurea maculosa) on surface runoff and sediment yield. Weed Technol. 3:627-631.

Lym, R.G. and D.A. Tober. 1997. Competitive grasses for leafy spurge (Euphorbia esula) reduction. Weed Technol. 11:787-792.

Menke, J.W. and M.J. Trlica. 1981. Carbohydrate reserve, phenology, and growth cycles of nine Colorado range species. J. Range Manage. 34:269-277.

Mueggler, W.F. and W.L. Stewart. 1980. Grassland and shrubland habitat types of western Montana. USDA Forest Service Gen. Tech. Rep. Int-66.
Chicoine, E.S., P.K. Fay, and G.A. Nielsen.
Olson, B.E. and R.T. Wallander. 1997. Biomass and carbohydrates of spotted knapweed and Idaho fescue after repeated grazing. J. Range Manage. 50:409-412.

Olson, B.E., R.T. Wallander, and J.R. Lacey. 1997. Effects of sheep grazing on a spotted knapweed-infested Idaho fescue community. J. Range Manage. 50:386-390.

Randall, J.M. 1996. Weed control for the preservation of biological diversity. Weed Technol. 10:370-383.

Rees, N.E., P.C. Quimby Jr., G.L. Piper, E.M. Coombs, C.E. Turner, N.R. Spencer, and L.V. Knutson. 1996. Biological Control of Weeds in the West. Western Society of Weed Science, USDA-ARS. Montana State Univ., Bozeman, Mont.

Roché, B.F., Jr. and C.J. Talbott. 1986. The collection history of Centaureas found in Washington State. Agr. Res. Center Res. Bull. XB0978. Washington State Univ., Pullman, Wash.

Sheley, R.L. and P.M. Rice. 1995. Invasion USA: A chronicle of weed invasion. In: Invasion exotics: A threat to the greater northwest! What is our status? Montana Weed Control Assoc. Annu. Conf. Proc. Missoula, Mont.

Sheley, R.L., J.S. Jacobs, and M.F. Carpinelli. 1998. Distribution, biology and management of diffuse knapweed (Centaurea diffusa) and spotted knapweed (Centaurea maculosa). Weed Technol. 12:353-362.

Spoon, C.W., H.R. Bowles, and A. Kulla. 1983. Noxious weeds in the Lolo National Forest. A situation analysis staff paper. USDA Forest Service North Region. Missoula, Mont.

Story, J.M., K.W. Boggs, W.R. Good, and R.M. Nowierski. 1989. The seed moth, Metzneria paucipunctella: its impact on spotted knapweed seed production and 2 seed head flies, Urophora spp, p. 172-174. In: P. K. Fay and J. R. Lacey (eds.), Proc. of the Knapweed Symp. Montana State Univ., Bozeman, Mont.

Strang, R.M., K.M. Lindsay, and R.S. Price. 1979. Knapweeds: British Columbia's undesirable aliens. Rangelands. 1:141-143.

Thompson, M. J. 1996. Winter foraging response of elk to spotted knapweed removal. Northwest Sci. 70:10-19.

Tyser, R.W. and C.H. Key. 1988. Spotted knapweed in natural area fescue grasslands: and ecological assessment. Northwest Sci. 62:151-160.

Watson, A.K. and A.J. Renney. 1974. The biology of Canadian weeds. Centaurea diffusa and C. maculosa. Can. J. Plant Sci. 54:687-701.

Weinmann, H. 1948. Underground development and reserves of grasses. J. Brit. Grassl. Soc. 3:115-140. 